\title{
CULTURAL APPROPRIATION: BRAZILIAN STAGE PRODUCTIONS OF SAMUEL BECKETT'S WAITING FOR GODOT
}

\author{
Anna Stegh Camati ${ }^{1}$ \\ ${ }^{1}$ UNIANDRADE, Curitiba, PR, Brasil
}

\begin{abstract}
The present article aims at discussing, first and briefly, the experimental features Samuel Beckett (1906-1989) imprinted in Waiting for Godot (1948-1949), among them the implosion of dramatic elements and the inscription of detailed performance instructions within the text itself, thus creating a performance model for which he used to demand respect. Thereupon, after addressing the 1955 first incursion of Godot in Brazil, a historical panorama of some outstanding stage productions of the play will be provided, mainly in terms of conceptualization and critical reception, in the light of theoretical perspectives by Oswald de Andrade, José Roberto O’Shea, Patrice Pavis, Peter Burke, among others.

Keywords: Samuel Beckett; Experimentalism; Waiting for Godot; Brazilian Stage Productions; Cultural Appropriation
\end{abstract}

\footnotetext{
"Professor of Theatre and Drama Studies in the Postgraduate Program in Literary Theory at UNIANDRADE University, Curitiba, PR, Brazil. She earned a doctorate in English Language and Anglo-American Literature at the University of São Paulo and carried out postdoctoral research in performance-oriented criticism of Shakespeare's dramaturgy at the Federal University of Santa Catarina. She has recently coorganized a collection of articles on Shakespeare, entitled Shakespeare sob múltiplos olhares (2016) and a collection of essays on Brazilian stage productions of Hamlet, entitled Hamlet no Brasil (2019). She has published articles on drama and theatre, intermediality, Shakespeare on the stage and screen, and cultural appropriations of Shakespeare's plays in Brazilian theatre. She is coeditor of the journal Scripta Uniandrade, Curitiba, and regional editor for Brazil of Global Shakespeares (MIT/Boston). E-mail: ascamati@gmail.com. ORCID: http://orcid.org/00000003-2460-1006.
} 
Endowed with immense creativity, Samuel Beckett (1906-1989), Irish novelist, poet, critic, playwright and theatre practitioner, left an indelible mark on the history of European Modernism and Postmodernism, becoming one of the major representatives of the artistic vanguards of his time. As far as the theatre is concerned, Beckett undertook radical experiments, thus creating new forms of expression which led to the emergence of groundbreaking innovations. He explored the utmost potentialities of the stage, crossed medial boundaries, and tested the ultimate possibilities of language in search of essential formal elements such as presence, movement and rhythm.

Between 1948 and 1949, Beckett wrote En attendant Godot [Waiting for Godot] in French, later translating the play into English. The French version was published in Paris in 1952 and the English translation was edited in New York in 1954. He repeated this experiment when writing Fin de partie [Endgame] in French between 1955 and 1956, translating it into English in 1958. Conversely, he wrote Krapp's Last Tape (1958) and Happy Days (1961) in English, providing French translations for both of them in 1960 and 1962 respectively. Besides his full-length plays, he also published a series of experimental short plays, and scripts for radio, television and cinema, such as Act Without Words I (1956), Act Without Words II (1956), All That Fall (1956), Embers (1959), Words and Music (1961), Cascando (1962), Play (1963), Comédie (1963), Come and Go (1965), Eh Joe (1965), Film (1965), Breath (1969), Not I (1972), That Time (1975), Footfalls (1975), Rockaby (1981), Ohio Impromptu (1981), Catastrophe (1982), What Where (1983), among others. In 1969, he was awarded the Nobel Prize, which consecrated him as one of the greatest writers of his time.

Martin Esslin, in his book The Theatre of the Absurd (1961), claimed that Beckett is one of the most illustrious absurdists. However, the vast and diversified literary output of the Irish playwright, which ranges from drama to the post-dramatic, resists categorization. Although Hans-Thies Lehmann has not acknowledged Beckett's and other Anglophone writers' experimentalisms in his polemical Postdramatisches Theater (1999), many of the short plays of the Irish playwright are reckoned as post-dramatic by contemporary theatre critics, among them Jonathan Kalb, Elinor Fuchs, Marc Robinson and others. Even in Waiting for Godot, his first successful project, Beckett displays non-dramatic elements, when he destroys the strictures of plot and transfers to the situation-the endless waiting per se-the interest that had hitherto belonged to dramatic action. Summing up, since the late 1940s, Beckett challenged the fundamental elements of drama-action, coherent dialogue, time, space and dramatic illusion-discussed by Peter Szondi in Theorie des Modernen Dramas (1956), thus imploding the pillars of tradition.

In 2003, during a lecture at the Goethe-Institute in São Paulo, published in Sala Preta, when asked whether theatre texts can be seen from a post-dramatic perspective, Lehmann answered positively. He mentioned Gertrude Stein's nondramatic plays as instances of textual forms that cannot be analyzed by dramatic theoretical frameworks, highlighting that Stein's landscape plays, written during the first decades of the twentieth century, no longer fitted the conventional model, 
since she had abolished the traditional structure, the predictable pace of dialogue and the logical development of the narrative ("Teatro pós-dramático" 2003, 15).

Beckett's Godot has been related to the landscape play by Elinor Fuchs in her innovative study titled The Death of the Character: Perspectives on Theater after Modernism (1996), in which she argues that "In Godot, the panoramic journey of life becomes a journey in place, without origin or destination. The linear succession of scenes and times native to its structure has either frozen in place or, with the same result, entropically diluted to a timeless landscape" (92). She further clarifies that although Gertrude Stein is considered the progenitor of the landscape play, and its proliferation has been attributed to mid-century directors and theatre groups, among them Jerzy Grotowski, Peter Brook and the Living Theatre, an important role in this respect must be assigned to Beckett, because it was only after his creative innovations that

experimental stage artists turn increasingly to staging theatrical worlds that no longer define themselves spatially against an unseen outside, or in a fictive temporal progression. These stage settings, sometimes representations of landscapes, as is often the case in Robert Wilson, but also imaginative hyperspaces, as in the productions of Richard Foreman, are performing worlds, elsewheres without elsewheres, imaginative spaces still shrewdly aware of their life in the theater. (Fuchs 93)

The close relationship between Stein and Beckett has been widely acknowledged. Marc Robinson compares Godot to Stein's play What Happened: A Play, in which no story is told and nothing happens,

at least according to criteria followed in most theaters of the day, where activity earned the name only when it corresponded to behavior seen outside the auditorium. But much happens dramatically: a kind of theatrical movement-with its mechanics determined inside the play and affecting the writing more than the subject-supplants merely imitative movement. (Robinson 1997, 13)

Likewise, Beckett directed his attention to the world of the play seen as a play, free from the strictures of rigid dramatic paradigms, thus probing into the depths of the human condition.

\section{Beckett's creation of a performance model in Waiting for Godot}

Stage directions or didaskalia were absent in Greek and Elizabethan theatres, rare in Neoclassic plays, but proliferated in the eighteenth and nineteenth centuries in bourgeois and realistic dramas. In Beckett's plays, however, stage directions become essential elements, since he inscribes the mise-en-scène within the text itself. As he provides detailed acting instructions inside his plays, they can be seen as complex performance texts, according to Marco de Marinis's and Patrice Pavis's terminologies. 
According to the semiological understanding of textuality, an image or group of images can be analyzed as texts, and a sculpture, a film, a musical passage, or the units of a theatrical production can become the object of textual analysis. Hence, "to speak of a performance text means to presume that a theatrical performance can be considered a text," since "the textual approach to performance is linked to the increasingly generalized conception of the 'text' in semiotic theory over the past few years" (De Marinis 1993, 47).

Beckett's text Waiting for Godot as performance model also relates to Pavis's notion of performance (or stage) text, defined as

the relationship of all the signifying systems used in performance, whose arrangement and interaction constitute the mise-en-scène. The notion of performance text is therefore an abstract and theoretical one, not an empirical and practical one. It considers the performance as a scale model in which the production of meaning may be observed. The performance text may be recorded in a production book, a Modellbuch or another metatext that presents a notation (necessarily an incomplete one) of the staging, and in particular of its aesthetic and ideological options. (Dictionary 1998, 261)

Beckett is unique in theatre history, because besides describing the scenic dimensions of his plays in production books or other descriptive manuals, he also inscribes them within his plays. The mise-en-scène

is always written into his texts in the most literal way, showing itself in a theatrical language where the word is never dissociated from the place where it is spoken or from the concrete language of the stage, where the word is never conceived outside the framework of the accompanying gesture, the movement, place, the physical stance and the bodily posture. (Chabert, qtd. in Kalb 1991, 44)

In this regard, there are some essential performance instructions in Godot that indicate fundamental actions within the scenic structure as, for example, the stage directions that announce the entrance of Pozzo and Lucky:

A terrible cry, close at hand. Estragon drops the carrot. They remain motionless, then together make a sudden rush towards the wings. Estragon stops half-way, runs back, picks up the carrot, stuffs it in his pocket, runs towards Vladimir who is waiting for him, stops again, runs back, picks up his boot, runs to rejoin Vladimir. Huddled together, shoulders hunched, cringing away from the menace, they wait. Enter Pozzo and Lucky. Pozzo drives Lucky by means of a rope passed round his neck, so that Lucky is the first to appear, followed by the rope which is long enough to allow him to reach the middle of the stage before Pozzo appears. Lucky carries a heavy bag, a folding stool, a picnic basket and a greatcoat. Pozzo a whip. (Beckett 21)

Furthermore, there are at least three other elements of theatricality to consider when analyzing Beckett's plays in performance: the production of 
presence, created by the actor's alignment of voice and gesture to cope with the essential rhythmic nature that informs the mood and the emotion of the words; the alternation of presentation and representation; and the establishment of a new type of audience/stage transaction.

When staged, the several segments of Beckett's plays act as frames, directing and focalizing the attention of the spectator to the production of presence. Maria Irene Fornes, a Cuban-American playwright, reports that when she was living in Paris, she saw Roger Blin's world première of Waiting for Godot. She reports that, despite not knowing a word in French, she was deeply impressed by the production: "But what was happening in front of me had a profound impact without even understanding a word. Imagine a writer whose theatricality is so amazing and so important that you could see a play of his, not understand one word, and be shook up" (qtd. in Robinson 1999, Fornes 63). She pointed out that the combination of gestures, blocking, rhythms of speech, tones of voice, designs of stage space and vaudeville techniques, transmuted into emotional truthfulness, produced effects of presence and influenced her subsequent work.

The alternation of presentational and representational techniques has become current in much contemporary performance art and avant-garde theater. In Godot, a great amount of lines the performers enunciate on stage are directed outward, addressing the audience, thus showing an alignment with the physicality of the post-dramatic:

[...] The two realms of meaning, presentational and representational, can be blended into a consistent atmosphere of ambiguity without the actors having to make constant shifts back and forth between them. Because it commits to an internal logic of clowning, his Godot is light-spirited, physical, and sensible. And because it is choreographed with such a firm hand, it transcends that simple clown-sense without forcing its clowns to act as authorial mouthpieces. (Kalb 35)

As has been made evident, the polyvalence of Beckett's performance style, inscribed in his texts, created a new model of performativity in theater history. Unlike performers directed by other theatre practitioners, the performers that Beckett directs

never act a double function onstage, for their characters do not distinguish between living and performing. They distinguish only between spontaneous and rehearsed action: spontaneity makes them feel momentarily free from the dulling effect of the repetition that is their actorly fate. In Godot, for example, all references to the audience ("that bog") and to the fact that a performance is occurring ("the Board") have meaning within the action as fleeting attempts at spontaneity, as if delivered behind an imaginary fourth wall. (Kalb 44)

It is widely known that Beckett repeatedly used to participate in rehearsals or even direct his own plays, most of the time demanding respect for his performance 
instructions and imposing limitations to the creativity of theatre practitioners. When he assumed the role of director, the actors trusted him completely, so as not to question the physical or vocal techniques he proposed to them and, in addition, "he had the good fortune of seeing many of his premières staged by two paradigms of loyalty-Roger Blin and Alan Schneider-who not only adhered on the very specific instructions in his scripts but also made frequent public comments about the propriety of that strictness" (Kalb 71). Even after Beckett's death, professionals who detained rights upon his dramaturgy struggled to maintain the rigidity of the crystallized mise-en-scène of the first performances. However, while in the 1950s there were quite a number of directors who still believed in the importance of following Beckett's staging project, such representatives have grown fewer and fewer with the passing of time. Among the newer generations of directors, Beckett's insistence on respect for his play scripts, stage directions included, is generally seen as pointless conservatism. Contemporary directors tend to reinterpret and devise new stage directions for Beckett's texts according to their own perceptions and impressions, advocating fresh insights and ignoring the predetermined rules of the so-called authentic Godot.

Since its world première in French, which took place at the Théâtre Babylone in Paris, in January 1953, directed by Roger Blin, Beckett's Waiting for Godot has been translated into many languages and performed on a global scale in theatres and non-conventional spaces, by amateurs and professionals. In September 1953, a German version of the play, titled Warten auf Godot, opened at Berlin's Schillertheater, directed by Walter Henn. Two years later, in 1955, two productions in English ensued: one in London, at the Arts Theatre, directed by Peter Hall, and the other in Dublin, at the Pike Theatre, under the direction of Alan Simpson. In January 1956, the first American performance was staged at the Coconut Grove Playhouse, in Miami and, later that year, Godot had its Broadway production at the John Golden Theatre, directed by Herbert Berghof. Most of these first performances initially met with unfavorable or mixed reviews, because the play caused total upsetting of audience expectations. In November 1957, however, when Godot was presented to the inmates of the San Quentin State Prison, directed by Herbert Blau, the analogous waiting situation of the prisoners conducted them to respond positively to the performance. Thereafter, the play has been successfully enacted in both hemispheres by prison inmates, multiethnic actors in a divided Sarajevo under siege, black actors during apartheid, or with casts made up exclusively of female characters.

\section{Theoretical Perspectives for Devising a Critical Panorama of Brazilian Stage Productions of Godot}

As far as the process of reconstitution of stage productions is concerned, I agree with José Roberto O'Shea who, in an article published in 2013, challenges the received difference between the notions of performance analysis and historical reconstruction. He argues that 
both processes engage in reconstruction, since any live performance, whether you saw it last night or it happened in Elizabethan England, vanishes; therefore whether or not having witnessed the performance, the analyst engages in and mediates the critical reconstruction, and the analytical procedures and constraints of the practice equally apply to seen and unseen productions. (8)

Hence, as in both instances reconstitution is an exercise which depends on a reconstructive investigation based on documents and reports, to achieve the purpose of rescuing a few of the most outstanding Brazilian Godots in terms of conceptualization and critical reception, I shall utilize some of the numerous tools at the disposal of the analyst recommended by Patrice Pavis (Analyzing 2006, 3152), among them theatre programs, interviews, publicity paratexts, press releases and reviews, photographs, articles and other scholarly studies, statements of intents provided by actors, directors and other members of the creative team, and short video clips of stage productions available at youtube.

When Godot is transposed to different sociocultural or political realities, new approaches, methodologies and performance tendencies are used. As we shall see, most Brazilian theatre practitioners do not limit themselves to operating cuts or language revisions, but tend to resort to experimental performance practices related to cultural anthropophagy, based on Oswald de Andrade's concept of cultural borrowing, formulated in his "Anthropophagic Manifest" in 1928. This statement of principles, in which the modernist Brazilian writer synthesizes his notion of creative cannibalism, confers legitimacy to the act of "devouring" foreign cultural legacies, which, after having been swallowed and digested, are regurgitated in new shapes and hues to express local realities.

Andrade's pioneering theoretical premises, which establish a dialogue between local culture and borrowed models, have by now become current in Brazilian and international criticism, anticipating contemporary reflections on intercultural theater politics and practices devised by Peter Burke, Patrice Pavis and others. Burke conveys that cultural encounters propitiate the insertion of contemporary moral and political concerns into the performance, providing a link between the issues foregrounded in the appropriated text and the local circumstances prevailing at the time of reception of the stage production (2009, 55-68). Pavis expresses a similar view when he asserts that intercultural exchange in the theatre implies in "a transaction between the source and target situations of enunciation that may glance at the source, but that has its eye chiefly on the target” (“Towards” 1992, 136-159).

\section{Brazilian Godots: New Theatricalities and Cultural Anthropophagy}

Brazilian performance history of Godot starts with the outstanding fact that Alfredo Mesquita's amateur production, enacted by students of the EAD (Escola de Arte Dramática) in São Paulo, premièred at the beginning of July 1955, one month before the renowned London production, directed by Peter Hall, which opened 
in August in that year. Two months later, due to critical and audience acclaim, the amateur actors were invited by Franco Zampari to perform professionally at the TBC (Teatro Brasileiro de Comédia), starting a new season on 6 September 1955, with the same cast: Luis Emanuele Corinaldi (Wladimir), Eugenio Barcellos (Estragon), Eduardo Waddington (Pozzo), Geraldo Mateos (Lucky), and Alceu Nunes (Boy). This production is minutely analyzed in an essay by Robson Corrêa de Camargo (“(Re)construindo" 2012, 1-19), in which he states that although Mesquita's production, in its visual aspects, established a close relationship with Roger Blin's performance (which Mesquita had seen in Paris), it was also marked by differences in performativity, mainly as concerns body language and comedic strategies. He also imparts that this first Brazilian production of Godot deals with the play within a frame of philosophical existentialism directly absorbed from European Beckettian reception.

During the Brazilian dictatorship period (1964-1985), artistic activities experienced permanent vigilance. Play-texts were cut, performances cancelled, and intellectuals and artists pursued, arrested and tortured by police officers. In spite of these adverse circumstances, two landmark productions of Godot, one directed by Flávio Rangel (1969) and the other by Antunes Filho (1977), were staged as a sign of resistance against authoritarian military rule.

Renata Pallottini, in her book Cacilda Becker: o teatro e suas chamas (12224), reports that in 1968, Cacilda Becker (1921-1969), Brazil's leading actress and political activist, who held a privileged position among her peers, got in touch with the politically engaged theatre director Flávio Rangel (1934-1988), who had been successively imprisoned for rebelling against the repressive measures of the military government. Cacilda asked him whether he knew any suitable theatre text capable of conveying the existential anguish, the sense of nothing to be done, but at the same time the desire to resist. Rangel suggested Waiting for Godot, a play he had just finished translating, encouraging her to play Estragon. In a few days, after reading the translated text, she accepted playing the male role, recommending Walmor Chagas, her former husband with whom she continued in close artistic partnership, to incarnate Wladimir.

On 13 December 1968, when the AI-5 [Institutional Act Number Five] was promulgated and censorship became extremely rigid, Rangel was arrested again. In prison, he concentrated his efforts to revise his translation of Godot and devise a performance aesthetics compatible with his own materialist reading. After being released from jail, he began rehearsals with Walmor Chagas (Wladimir), Cacilda Becker (Estragon), Carlos Kroeber (Pozzo), Carlinhos Silveira (Lucky) and Cacilda's adolescent son in the role of the Boy. Pallottini (123) contends that Cacilda incarnated her role with great seriousness and intensity: late one night the actress was taken by surprise, among carrots and turnips in her costume, a cigarette stub, living full time the character she had been assigned to.

The critically acclaimed Godot, directed by Rangel, premièred at the Cacilda Becker Theatre in Rio de Janeiro on 17 March 1969. It was also presented at the official inauguration of The Municipal Theatre of São Carlos in April 1969. On 
6 May 1969, however, the season in Rio was tragically interrupted. During an intermission, a few moments before her return to the stage, Cacilda suffered a brain aneurysm. She was immediately taken to hospital in her clown costume, where after 38 days in coma she passed away on 14 June 1969. This tragic event conferred mythical status to the production and marked the beginning of the Brazilian tradition of women playing male roles.

Cacilda Becker's creation of Estragon was almost unanimously celebrated by audiences and critics. Alberto D’Aversa, in his review in O Diário de São Paulo, asserted: "Cacilda has succeeded in creating a new acting style, hybrid and unique, highlighting the pathetic derision of the character. Her fragile figure, graceless and chaplinesque, contrasted with her clownesque mask illuminated by inner life and wisdom" (qtd. in Pallotinni 128, my translation). ${ }^{1}$ The humorist Jô Soares remarked that Cacilda died on stage, a place she loved above all, pointing out a curious detail: "When she was taken to hospital, still wearing her clown costume, she removed her red clown nose and handed it over to the actor Líbero Lipoli, recommending 'save it for me', thus believing she would soon come back. And I am certain she has returned. Each time I step on stage, the creaking wooden boards denounce her presence" (qtd. in Pallottini 131).

The fact that Cacilda died on stage amidst great critical recognition turned her into a legend. Décio de Almeida Prado wrote, "Cacilda stands out among her peers because of her intensity, the commitment she showed when taking on a role, even wearing herself physically out if necessary. At her best moments, she achieved transfiguration, turning into a burning flame on stage" (Heliodora 1987, 278). Barbara Heliodora paid homage to the actress in Jornal do Brasil on 21 June 1969, reasserting that Cacilda had always channeled her name and position in benefit of the theatre with overwhelming courage and determination. The closing statement of the panegyric reads: "Cacilda passed away.... Her example remains, to which we must resort whenever necessary. Now that she has left us, Brazilian theatre is greatly impoverished" (585).

The tightening pressure of the military rule during the next fifteen years engendered successive political waves of resistance and strengthened the impetus to fight against the constant constraints imposed by censors. For obvious reasons, Brecht's dramaturgy and Augusto Boal's "theatre of the oppressed" were elected as the most adequate models for political militancy. At the same time, theatre professionals felt the need to bring up to date the formal principles of Brazilian Modernism, developing an aesthetic current based on Oswald de Andrade's anthropophagic manifest, which implied ritual devouring of foreign sources to express aspects of local culture in new ways. Some of the most prolific theatre practitioners in Brazil, among them José Alves Antunes Filho, José Celso Martinez Corrêa and Gabriel Villela, staged Beckett's Godot in this context.

In spite of Beckett's objection to casts of female actors, Antunes Filho (19292019), one of the most celebrated Brazilian theatre practitioners, directed the first Brazilian all-female version of Godot, which premièred in Brasilia, in May 1977 and, after extensive tours along the Brazilian coast from Manaus to Porto Alegre, 
the production was presented in São Paulo in October 1977, first at the Teatro FAAP and later at the Teatro Municipal, always receiving considerable press coverage and great audience acclaim. The all-female cast of this memorable production was composed by Eva Wilma (Wladimir), Lilian Lemmertz (Estragon), Lélia Abramo (Pozzo), Maria Yuma (Lucky), and Sonia Golding or Vera Lima (Boy).

In 2007, Eva Wilma reported to Folha de S. Paulo that after reading Waiting for Godot, translated by Flávio Rangel, she realized that the play mirrored the political unrest and suspension of legal rights adopted by the military government in 1977. She further recalled that when she proposed the idea of staging Godot with an all-female cast to Antunes Filho, he embraced the project with enthusiasm, later writing a significant metatext for the program of the production, which might be read as "Waiting for Democracy" (Wilma 2007).

Recently, in conversation with Caio Liudvik to Folha de S. Paulo, Antunes Filho disclosed that his Godot emerged out of the ferment of ideas current in 1977:

When I staged Godot, I was conditioned by the discussion of the decline of the West, the downfall of civilization, the hell of Auschwitz, Adorno, Walter Benjamin, the theatre of the absurd, and the notion that nothing makes sense. I introduced references to Hitler into the production and set it in the post-Holocaust period in order to convey a moment of crisis, namely the end of modernism and the beginning of post-modernism, a time when established values were upturned and undermined. I also referred to the Brazilian dictatorship.... But what really perplexed me in Godot is that in the first act the tree is leafless, and in the second act three or four leaves are visible. What does this mean? At first thought, that the situation is terrible, absurd, so it's useless to go on. However, we do go on, and if we continue communicating, it's because we want to proceed. It has to do with Schopenhauer's "will power." We hold on to life. ... Iconoclastic negation constitutes an affirmation, it has an affirmative side. It means there is hope, at least hope in language, thus it is possible to attribute a mystical meaning to words, a theological sense. (Liudvik 2006)

Furthermore, to intensify the oppressiveness of the sociopolitical Brazilian context, unusual sound designs, composed of musical excerpts from German Nazi rallies, and alarm sirens drew attention to authoritarian discourses and postures (V. Santos 2019). As evinced above, in the absence of a clear key for interpretation of the play, Antunes Filho appropriated the openness of Beckett's text as pretext for a political reading, introducing contemporary global and local references into the performance text. He reframed Godot in consonance with Andrade's concept of creative cannibalism in both content and form, tracing parallels between text, international circumstances and the local situation in Brazil.

In 1998, José Celso Martinez Corrêa (1937-), known as ZéCelso, one of the most influential avant-garde artists and co-founder of the renowned São Paulo-based Teatro Oficina, adapted Cacilda Becker's biography for the stage, appropriating the climactic moment in 1969 when, as we have seen, the actress, incarnating Estragon, suffered a brain aneurysm during the intermission of Waiting for Godot. His production titled Cacilda is an orgiastic memory play, in which the actress lies 
in coma recollecting, in back and forth time flashes, her private experiences and professional life mixed up with Brazilian theatre history (M. Santos 1998). The performance, which lasts five hours and a half, begins with a prophetic scene set in Hades, where Persephone prophesies the renewal of the Earth and Cacilda's life is chosen as an expression of this augury. Then, facts and fictions as well as real people and fictional characters are interwoven in the construction of the myth. The characters of Godot and other plays, which marked the professional career of the actress, are resignified by Zé Celso's hybrid performance aesthetics, which combines circus techniques, slapstick, sex, pornography, carnivalization in the Bakhtinian sense, and strategies developed by Brecht and Artaud, reconfigured in the light of Andrade's anthropophagic manifest.

When Zé Celso was invited by Monique Gardenberg to present a new version of Godot in 2001, at the Centro Cultural Banco do Brasil in Rio de Janeiro, he opted for a farcical, carnivalesque approach. He reports that he decided to reframe the relationship of dependency between Vladimir (Selton Mello) and Estragon (Otávio Müller) into a ritual of erotic energy, inspired by a photographic essay he had bought shortly before deciding to stage the play, shot by Roberto Garcia in 1884, which showed two tramps in erotic circumstances in the streets of Rio de Janeiro. He further asseverated that when he reread Beckett's text, he found a series of textual fragments that corroborated his irreverent and anarchic stance, which he combined with Brazilian social realities and problems, such as poverty and violence (V. Santos 2001).

In the same vein, cultural anthropophagy gained ascendancy in another allfemale production of Godot in 2006, loosely inspired in a recent translation by Fábio de Souza Andrade (2005), and directed by the renowned Brazilian theatre practitioner Gabriel Villela (1958-), who mounted a stage version, especially conceived for the Basement Space of Sesc Belenzinho in Rio de Janeiro, a former silo remodeled into a theatre in the round in 2003. The performance, which extended from 3 February to the end of March 2006, was part of the celebrations of the $100^{\text {th }}$ anniversary of Beckett's birth. When asked why he chose Godot to pay homage to Beckett, Villela made reference to the adaptability of the text in terms of appropriation and borrowings:

As the meaning of Godot is not determined, you are allowed to read it according to your own vision and values. The sense of waiting is paramount, because it is the synthesis of human life.... Hamlet and Godot are two new testaments. They guide and govern humanity in the sense of before and after. (qtd. in Belusi 2006)

Villela opted for a contemporary, ecological reading. The scenic space in the form of an arena was entirely appropriate to shape the performance space as a circus ring: the two concentric circles drawn in chalk expressed the circularity of the fictional universe. The inner circle displayed a small wooden wheel, a tight space where Didi and Gogo act out their circular, static movements in the process of their endless waiting, and the larger circle, also an acting area, was surrounded by the audience. The spatial code of the circus allowed the all-female cast, constituted 
by Magali Biff(Vladimir), Bete Coelho (Estragon), Lavínia Pannunzio (Pozzo), and Vera Zimmermann (Lucky and Boy), to take a series of liberties with Beckett's play, making use of clowning, mime, puppetry and physical acting techniques inherited from commedia dellarte. The clowning atmosphere, in turn, contrasted with the stifling ambience and set design: signs of nature devastation, built into the inner circle of the ring-a barren tree and dried out earth-clods-simulated a desolate territory laid waste by forest fires as found in Brazil or elsewhere. ${ }^{2}$

Visual elements, such as costumes and props, also indicated the anthropophagic impulse of the production. In his Godot, instead of deploying his aesthetics of excess as usual, Villela opted for simplicity. The costumes of the actresses were handcrafted locally, with the exception of the white linen tunics used over their outfits. According to the director, the linens were produced in southern France and modelled on nightgowns used in Parisian shelters during Nazi invasions. Although all five characters employ clown acting techniques, only Pozzo, who embodies power and domination, wears a black clown nose instead of a red one; and one of the hands of both, Pozzo and Lucky, is mechanical to indicate their relationship of ringmaster and slave (V. Santos 2006; Villela 2006).

More recently, a series of new anthropophagic experiments have been successfully developed, among them the stage production directed by Elias Andreato (2016), ${ }^{3}$ who uses clowning performance practices and shapes the scenic space as an arena in the form of a huge clock (even the tree is stylized into two enormous clock-hands), which is valid considering that clock time plays an extremely important role in the play; and the version of Garagem 21 (2016-2017), ${ }^{4}$ a theatre company whose hybrid performance aesthetics includes elements borrowed from Tadeusz Kantor, comics and contemporary dance concepts.

\section{Final Remarks}

Since 1955, there has been an ongoing process of performing Godot in Brazil in different historical and cultural contexts, generating new communicative energies and unusual expressive potentials. The play has become part of the Brazilian imaginary; most theatre practitioners congregate heterogenous cultural elements, from popular traditions to innovative aesthetic tendencies, and combine them with Brazilian social realities and problems, not taking into account critical fortunes or essentialist practices.

Although most of the Brazilian Godots discussed in the present article are anthropophagic appropriations of Beckett's play, transplanted into rich and varied contexts to convey local values and ideologies, this does not mean it is a general rule. There are theatre practitioners who tend to follow closely the textual and performance orthodoxies sanctioned by the Irish playwright, among them Rubens Rusche, one of the most respected Beckett scholars, whose expertise is notable and performance style extremely inventive.

Within the tradition of staging Beckett's Godot, the dialogical nature, cultural prestige, and global appeal of the play make it a favorite choice for new critical 
endeavors on page, stage and screen. According to Roland Barthes' viewpoint, Godot has progressively moved away from elitist playgoers and been associated with popular theatre. Like boulevard plays, Godot has gained large audiences, spreading out because it "contained within itself the specific properties of its time" (2007, 98). In this sense, the play has acquired mythical status, inviting theatre practitioners all over the world to find new localities and social contexts in which to translate the endless waiting of the two tramps. By now, their plight has been continually appropriated and rejuvenated, both locally and globally.

While in the 1940s and 1950s Godot was seen as an elitist product, by and by it liberated itself from the hermetic imprisonment it had been launched into by renowned critics, the guardians of generic purity. Against all odds, the play conquered popular theatre audiences everywhere, validating Barthes's prognosis that: "sociologically, Godot is no longer a vanguard play" (95).

Notes

1. Henceforth, all translations of quotations from books or other sources not available in English are mine.

2. Fragments of Gabriel Villela's production of Godot (2006) can be visualized on youtube: $<$ https://www.youtube.com/watch?v=qcw6iOfkztg $><$ https://www.youtube. com/watch?v=TF7jufp6k1o $>\langle$ https://www.youtube.com/watch?v=1SWsStGvlas $>$.

3. Fragments of Elias Andreato's version of Godot (2016), showing his inventive scenic space, are available at youtube: <https://www.youtube.com/watch?v=AQz7iw $\mathrm{KLaBQ} \& \mathrm{t}=215 \mathrm{~s}>$.

4. Fragments of Godot by Cia. Garagem 21 (2016-2017), directed by César Ribeiro, are available at: $<$ https://www.youtube.com/watch?v=tYI9W0J9EY0 >

\section{References}

Andrade, Oswald. "Manifesto antropófago". Revista de Antropofagia, vol. I, no. 1, 1928, pp. 25-31.

Antunes Filho. Espetáculo de clowns. Folha de S. Paulo. Caderno Mais. 09/04/2006, p. 6. <https://www1.folha.uol.com.br/fsp/mais/fs0904200618.htm>.

Barthes, Roland. "Godot adulto." Escritos sobre o teatro, translated by Mário Laranjeira, Martins Fontes, 2007. pp. 94-8.

Beckett, Samuel. Esperando Godot, translated by Flávio Rangel, Abril Cultural, 1976. Esperando Godot, translated by Fábio de Souza Andrade, Cosac Naify, 2005. Waiting for Godot: A Tragicomedy in Two Acts. Faber and Faber, 1979.

Belusi, Soraya. Quem tem medo de Beckett? O Tempo. 13/04/2006. <https://www. otempo.com.br/diversao/magazine/quem-tem-medo-de-beckett1.326388>

Burke, Peter. Cultural Hybridity. Polity Press, 2009.

Camargo, Robson Corrêa de. "Samuel Beckett: $(\mathrm{Re})$ construindo imagens e memórias." Fênix: Revista de História e Estudos Culturais, vol. 9, ano IX, no. 2, 2012, pp. 1-19.

De Marinis, Marco. The Semiotics of Performance, translated by Áine O'Healy, Indiana University Press, 1993.

Esslin, Martin. The Theatre of the Absurd. Anchor Books, Doubleday and Company, 1961. 
Fuchs, Elinor. The Death of the Character: Perspectives on Theater After Modernism. Indiana University Press, 1996.

Heliodora, Barbara. "Cacilda morreu." Barbara Heliodora. Escritos sobre o Teatro, organized by Claudia Braga, Editora Perspectiva, 2007. pp. 582-85.

Kalb, Jonathan. Beckett in Performance. Cambridge University Press, 1991.

Lehmann, Hans-Thies. Postdramatisches Theater. Verlag der Autoren, 1999.

. “Teatro pós-dramático e teatro político." Sala Preta: Revista do Departamento de Artes Cênicas, ECA-USP, no. 3, 2003, pp. 9-19.

Liudvik, Caio. Espetáculo de clowns. Folha de S. Paulo. Caderno Mais. 09.04.2006. < https://www1.folha.uol.com.br/fsp/mais/fs0904200618.htm>.

O'Shea, José Roberto. "Impossibilities and Possibilities: the Challenges of Dramatic Performance Analysis." Estudos Anglo-Americanos, no. 40, 2013, pp. 6-18.

Pavis. Patrice. Analyzing Performance: Theatre, Dance and Film, translated by David Williams, The University of Michigan Press, 2006.

Pavis, Patrice. Dictionary of the Theatre: Terms, Concepts and Analysis, translated by Christine Shantz, University of Toronto Press, 1998.

Pavis, Patrice. "Towards Specifying Theatre Translation." Theatre at the Crossroads of Culture, translated by Loren Kruger, Routledge, 1992. pp. 136-59.

Prado, Décio de Almeida. "Adeus a Cacilda." Exercício Findo. Perspectiva, 1987. pp. 277-79.

Robinson, Marc, editor. Maria Irene Fornes. The Johns Hopkins University Press, 1999.

Robinson, Marc. The Other American Drama. The Johns Hopkins University Press, 1997.

Santos, Mario Vitor. Zé Celso revive Cacilda com Bete Coelho, sexo e drogas. Folha de S. Paulo. 5/09/1998. < https://www1.folha.uol.com.br/fsp/ilustrad/fq05099803. htm>

Santos, Valmir. A solidão povoada de Antunes Filho. Telejornal: leituras de cena. 10/5/2019. < https://teatrojornal.com.br/2019/05/a-solidao-povoada-deantunes-filho/>.

Santos, Valmir. Godot ecológico. Folha de S. Paulo. Ilustrada. 31/01/2006. <https:// www1.folha.uol.com.br/fsp/ilustrad/fq3101200607.htm>.

Santos, Valmir. Zé Celso monta no Rio Esperando Godot, clássico de Beckett. Folha de S. Paulo. 16/07/2001.<https://wwwl.folha.uol.com.br/folha/ilustrada/ ult90u15513.shtml>

Szondi, Peter. Theorie des Modernen Dramas 1880-1950. Suhrkamp Verlag, 1956.

Villela, Gabriel. Esperando Godot estreia com elenco feminino. Estado de S. Paulo. 3/2/2006.<https://cultura.estadao.com.br/noticias/musica,esperando-godotestreia-com-elenco-feminino,20060203p3667>

Wilma, Eva. Eva Wilma defende o teatro de ideias. Entrevista. Folha de S. Paulo. Ilustrada. 9/5/2007. <https://www1.folha.uol.com.br/fsp/ilustrad/fq0905200709. htm>. 